\title{
KEBERHASILAN PEMERANGKAPAN TIKUS (Rattus exulans) DENGAN JENIS UMPAN BERBEDA DI KEBUN RAYA LIWA LAMPUNG BARAT
}

\author{
Destika Putri Gumay ${ }^{1}$, Mohammad Kanedi ${ }^{1}$, Endah Setyaningrum ${ }^{1}$, \\ Hendri Busman ${ }^{1}$
}

1Jurusan Biologi, Fakultas Matematika dan Ilmu Pengetahuan Alam Universitas Lampung

[email korespondensi: dputrigumay@gmail.com]

\begin{abstract}
Abstrak : Rattus Exulan Success With Various Types Of Baits In Liwa Botanical Garden Of West Lampung. Rats are wild animals that can adapt to human life. Rats also become important pests in human life, whether in the agriculture sector, plantations sector, settlements sector, and health sector. Rats are classified into the Order of Rodentia and the Family of Muridae. This study aims to determine the success rate of rat trapping using four different types of bait in the form of roasted coconut, salted fish, chicken bones and sweet potatoes by using a single live trap. This research was conducted in the West Lampung Liwa Botanical Garden on 17th -26th October 2019. The total traps which were used were 8 traps in a single installation with a total of 10 traps. Conducted observations consi.der the number of trapped rats, types of trapped rats, gender and size of rats, as well as rats' most attracting bait. The result of this study is the Trap of Success (KP) of rats with different types of bait. Rats preferred roasted coconut bait shown by its highest trapping success at $87.5 \%$.The trapped species are (Rattus exulans) Polynesian rats, (Suncus murinus) house shrews and (Hylomys suillus) short-tailed gymnure. Female rats were having a bigger amount ( 8 tails) rather than male rats ( 3 tails). Rats with size $<70 \mathrm{gr}$ are having a bigger number ( 8 tails) compared to size $>70 \mathrm{gr}$ ( 3 tails).
\end{abstract}

Keywords: the trap of success, single life trap, type of baits

\begin{abstract}
Abstrak : Keberhasilan Pemerangkapan Tikus (Rattus exulans) Dengan Jenis Umpan Berbeda di Kebun Raya Liwa Lampung Barat. Tikus merupakan hewan liar yang mampu beradaptasi dengan kehidupan manusia. Tikus juga menjadi hama penting dalam kehidupan manusia, baik dalam bidang pertanian, perkebunan, permukiman, dan kesehatan. Tikus digolongkan ke dalam Ordo Rodentia dan Famili Muridae. Penelitian ini bertujuan untuk mengetahui tingkat keberhasilan pemerangkapan tikus menggunakan empat jenis umpan yang berbeda berupa kelapa bakar, ikan asin, tulang ayam dan ubi jalar dengan meggunakan perangkap hidup tunggal (single live trap). Penelitian ini dilakukan di Kebun Raya Liwa Lampung Barat pada tanggal 17-26 Oktober 2019. Total perangkap yang digunakan adalah 8 perangkap dalam sekali pemasangan dengan total 10 kali pemasangan perangkap. Pengamatan yang dilakukan adalah jumlah tikus terperangkap, jenis tikus yang terperangkap, jenis kelamin dan ukuran tikus, serta umpan yang paling banyak menarik tikus sehingga terperangkap. Hasil penelitian ini adalah keberhasilan pemerangkapan (KP) tikus dengan jenis umpan yang berbeda. Tikus lebih menyukai umpan kelapa bakar dengan keberhasilan pemerangkapan paling tinggi yaitu $87,5 \%$. Spesies yang terperangkap adalah (Rattus exulans) tikus ladang, (Suncus murinus) cecurut rumah dan (Hylomys suillus) cecurut babi. Tikus dengan jenis kelamin betina lebih banyak didapat ( 8 ekor) dibandingkan tikus jantan ( 3 ekor). Tikus dengan ukuran $<70 \mathrm{gr}$ lebih banyak didapat (8 ekor) dibandingkan dengan ukuran $>70 \mathrm{gr}$ ( 3 ekor).
\end{abstract}

Kata kunci: keberhasilan pemerangkapan, perangkap hidup tunggal, jenis umpan. 


\section{PENDAHULUAN}

Tikus adalah hewan pengerat (rodensia) yang lebih dikenal manusia sebagai hama tanaman pertanian, perusak barang di gudang, dan hewan pengganggu yang menjijikkan di perumahan. Belum banyak diketahui dan disadari bahwa kelompok hewan ini juga membawa, menyebarkan, dan menularkan berbagai penyakit kepada manusia, ternak, dan hewan peliharaan. Rodensia komensal yaitu rodensia yang hidup di dekat tempat hidup atau kegiatan manusia dan perlu diperhatikan dalam penularan penyakit. Penyakit yang ditularkan dapat disebabkan oleh infeksi berbagai agent penyakit dari kelompok virus, rickettsia, bakteri, protozoa, dan cacing. Penyakit tersebut dapat ditularkan kepada manusia secara langsung oleh ludah, urin dan fesesnya atau melalui gigitan ektoparasitnya (Komariah, 2010). Tikus berperan sabagai hama kosmopolit yang dapat merusak tanaman padi. Selain sebagai hama, tikus juga dikenal sebagai sumber sekaligus penyebar penyakit zoonosis seperti pes, leptospirosis, salmonellosis, radang otak, radang paru, diare darah, dan gastritis akibat parasit (Suyanto, 2006).

Tikus adalah satwa liar yang bisa beradaptasi dengan kehidupan manusia. Tikus digolongkan ke dalam Ordo Rodentia (hewan mengerat) dan Famili Muridae. Kehadiran tikus dapat bersifat menguntungkan dan merugikan. Sifat menguntungkan yaitu dapat digunakan sebagai hewan percobaan di laboratorium (Priyambodo, 2003). Sifat merugikan yaitu tikus berperan sebagai hama. Tikus menjadi hama penting dalam kehidupan manusia, baik dalam bidang pertanian, perkebunan, permukiman, dan kesehatan (Meehan, 1984). Peran tikus sebagai hama karena mengasah gigi serinya yang tumbuh terus sepanjang hidupnya, dengan cara mengerat benda-benda keras di sekitarnya (Marbawati dan Ismanto 2011).Tujuan dari penelitian adalah untuk mengetahui tingkat keberhasilan pemerangkapan tikus menggunakan beberapa jenis umpan berbeda dengan menggunakan perangkap hidup tunggal (single live trap), mengetahui spesies tikus yang tertangkap dan mengetahui jenis kelamin dan bobot tubuh dari tikus yang tertangkap.

\section{METODE}

Jenis penelitian ini adalah penelitian deskriptif menggambarkan keberhasilan pemerangkapan tikus dengan 4 jenis umpan berbeda dan jenis keberadaan jenis tikus yang berada di Kebun Raya Liwa Lampung Barat. Penelitian ini dilakukan di Kebun Raya Liwa Lampung Barat, pada tanggal 17-26 Oktober 2019. Pemasangan perangkap dilakukan pada waktu sore hari pukul 16.00 WIB kemudian perangkap diambil esok harinya antara pukul 06.00 - 09.00 WIB. Jumlah perangkap sebanyak 8 perangkap dengan umpan kelapa bakar, ikan asin, tulang ayam, dan ubi jalar dalam sekali pemerangkapan dilakukan dalam 10 hari berturut turut. Perangkap diletakkan pada rumbun bambu dan kebun pembibitan. Identifikasi spesies yang tertangkap hanya dilakukan identifikasi morfologi luar saja.

\section{HASIL}

Hasil penelitian tentang karakter kuantitatif tikus dan cecurut yang tertangkap berupa nama spesies, jenis kelamin, bobot tubuh, panjang badan, panjang ekor, panjang total, lebar telinga, dan panjang kaki. Seperti $R$. exulans yang didapatkan pada hari ke 1, 2 dan 6, S. murinus yang didapatkan pada hari ke $3,5,6,8$ dan 10 dan $H$. suillus didapatkan pada hari ke 7 . Jenis kelamin $R$. exulans yang paling banyak didapatkan adalah betina, dengan bobot tubuh kisaran 19 - 88 gram, panjang badan 8 - $15 \mathrm{~cm}$, panjang ekor 9 - $16 \mathrm{~cm}$, panjang total $17-31 \mathrm{~cm}$, lebar telinga $1,3-1,7 \mathrm{~cm}$ dan panjang kaki 2,1 - 2,9 cm. Untuk data selengkapnya pada Tabel 1 .

Hasil penelitian tentang spesies yang terperangkap memiliki ciri kualitatif yang sama pada masingmasing spesies. Seperti ciri kualitatif pada Rattus exulans memiliki tekstur rambut yang agak kasar, bentuk 
hidung kerucut, bentuk badan silindris, kekuningan, warna badan bagian perut kelabu putih, dan warna ekor coklat warna badan bagian punggung coklat gelap. Untuk selengkapnya pada Tabel 2.

Tabel 1. Karakter kuantitatif tikus dan curut yang terperangkap

\begin{tabular}{|c|c|c|c|c|c|c|c|c|c|}
\hline Hari ke & Spesies & Seks & $\begin{array}{l}\text { BT } \\
(\mathrm{g})\end{array}$ & $\begin{array}{c}\text { PB } \\
(\mathrm{cm})\end{array}$ & $\begin{array}{c}\text { PE } \\
(\mathrm{cm})\end{array}$ & $\begin{array}{c}\text { PT } \\
(\mathrm{cm})\end{array}$ & $\begin{array}{c}\mathrm{LT} \\
(\mathrm{cm})\end{array}$ & $\begin{array}{c}\text { PK } \\
(\mathrm{cm})\end{array}$ & $\begin{array}{c}\text { Jenis } \\
\text { umpan }\end{array}$ \\
\hline 1. & $\begin{array}{l}\text { Rattus } \\
\text { exulans }\end{array}$ & Betina & 70 & 14,5 & 15,5 & 30 & 1,3 & 2,5 & $\begin{array}{l}\text { Kelapa } \\
\text { bakar }\end{array}$ \\
\hline 2. & $\begin{array}{l}\text { Rattus } \\
\text { exulans }\end{array}$ & Jantan & 81 & 15 & 16 & 31 & 1,7 & 2,9 & $\begin{array}{l}\text { Kelapa } \\
\text { bakar }\end{array}$ \\
\hline 3. & $\begin{array}{l}\text { Suncus } \\
\text { murinus }\end{array}$ & Jantan & 69 & 15 & 7 & 22 & 0,9 & 1,9 & $\begin{array}{l}\text { Ikan } \\
\text { asin }\end{array}$ \\
\hline 4. & - & - & - & - & - & - & - & - & - \\
\hline 5. & $\begin{array}{l}\text { Suncus } \\
\text { murinus }\end{array}$ & Betina & 59 & 11 & 6,5 & 17,5 & 1 & 1,3 & $\begin{array}{l}\text { Kelapa } \\
\text { Bakar }\end{array}$ \\
\hline \multirow{4}{*}{6.} & $\begin{array}{l}\text { Rattus } \\
\text { exulans }\end{array}$ & Jantan & 88 & 15 & 15 & 30 & 1,7 & 2,6 & $\begin{array}{l}\text { Kelapa } \\
\text { Bakar }\end{array}$ \\
\hline & $\begin{array}{l}\text { Rattus } \\
\text { exulans }\end{array}$ & Betina & 52 & 11 & 14 & 25 & 1,7 & 2,5 & $\begin{array}{l}\text { Kelapa } \\
\text { Bakar }\end{array}$ \\
\hline & $\begin{array}{l}\text { Rattus } \\
\text { exulans }\end{array}$ & Betina & 19 & 8 & 9 & 17 & 1,4 & 2,1 & $\begin{array}{l}\text { Kelapa } \\
\text { Bakar }\end{array}$ \\
\hline & $\begin{array}{l}\text { Suncus } \\
\text { murinus }\end{array}$ & Betina & 50 & 11,5 & 6,5 & 18 & 1 & 1,4 & $\begin{array}{l}\text { Ubi } \\
\text { Jalar }\end{array}$ \\
\hline 7 & $\begin{array}{l}\text { Hylomys } \\
\text { suillus }\end{array}$ & Betina & 65 & 13 & 1 & 14 & 1,2 & 2,1 & $\begin{array}{l}\text { Ikan } \\
\text { Asin }\end{array}$ \\
\hline 8. & $\begin{array}{l}\text { Suncus } \\
\text { murinus }\end{array}$ & Betina & 46 & 12,5 & 6,5 & 19 & 0,9 & 1,4 & $\begin{array}{l}\text { Kelapa } \\
\text { Bakar }\end{array}$ \\
\hline 9. & - & - & - & - & - & - & - & - & - \\
\hline 10. & $\begin{array}{l}\text { Suncus } \\
\text { murinus }\end{array}$ & Betina & 43 & 12 & 6 & 18 & 1 & 1,4 & $\begin{array}{l}\text { Ikan } \\
\text { Asin }\end{array}$ \\
\hline
\end{tabular}

Keterangan :

BT : Bobot Tubuh (gr)

PKB : Panjang kepala-badan $(\mathrm{cm})$

$P E$ : Panjang Ekor $(\mathrm{cm})$

PT : Panjang Total $(\mathrm{cm})$

LT : Lebar Telinga $(\mathrm{cm})$

PK : Panjang Telapak Kaki $(\mathrm{cm})$

Tabel 2. Karakter kualitatif tikus dan curut yang terperangkap

\begin{tabular}{|c|c|c|c|c|c|c|}
\hline Spesies & $\begin{array}{l}\text { Tekstur } \\
\text { Rambut }\end{array}$ & $\begin{array}{l}\text { Bentuk } \\
\text { Hidung }\end{array}$ & $\begin{array}{l}\text { Bentuk } \\
\text { Badan }\end{array}$ & $\begin{array}{c}\text { Warna } \\
\text { badan } \\
\text { bagian } \\
\text { punggung }\end{array}$ & $\begin{array}{c}\text { Warna } \\
\text { badan } \\
\text { bagian } \\
\text { perut }\end{array}$ & $\begin{array}{c}\text { Warna } \\
\text { ekor }\end{array}$ \\
\hline $\begin{array}{l}\text { Rattus } \\
\text { exulans }\end{array}$ & $\begin{array}{l}\text { Agak } \\
\text { Kasar }\end{array}$ & Kerucut & Silindris & $\begin{array}{c}\text { Coklat } \\
\text { Kekuningan }\end{array}$ & $\begin{array}{l}\text { Kelabu } \\
\text { Putih }\end{array}$ & $\begin{array}{l}\text { Coklat } \\
\text { Gelap }\end{array}$ \\
\hline $\begin{array}{l}\text { Hylomys } \\
\text { suillus }\end{array}$ & $\begin{array}{l}\text { Agak } \\
\text { Kasar }\end{array}$ & Kerucut & Silindris & Coklat Gelap & $\begin{array}{l}\text { Coklat } \\
\text { Gelap }\end{array}$ & $\begin{array}{l}\text { Coklat } \\
\text { Gelap }\end{array}$ \\
\hline $\begin{array}{l}\text { Suncus } \\
\text { murinus }\end{array}$ & Halus & Kerucut & Silindris & Kelabu & Kelabu & Kelabu \\
\hline
\end{tabular}

Hasil penelitian tentang data berupa

berdasarkan empat jenis umpan keberhasilan pemerangkapan tikus 
tersebut umpan kelapa bakar yang memiliki keberhasilan pemerangkapan paling tinggi yaitu sebesar $87,5 \%$ dan pada tulang ayam paling rendah bahkan tikus dan cecurut tidak tertarik sama sekali. Data selengkapnya pada Tabel 3.

Tabel 3. Keberhasilan pemerangkapan (KP) menggunakan empat jenis umpan yang berbeda-beda.

\begin{tabular}{lccc}
\hline Jenis Umpan & $\begin{array}{c}\text { Jumlah } \\
\text { Perangkap } \\
\text { (Buah) }\end{array}$ & $\begin{array}{c}\text { Tikus dan } \\
\text { Curut yang } \\
\text { didapat (Ekor) }\end{array}$ & $\begin{array}{c}\text { Keberhasilan } \\
\text { Pemerangkapan } \\
\text { (\%) }\end{array}$ \\
\hline Ikan Asin & 8 & 3 & $37,5 \%$ \\
\hline Tulang Ayam & 8 & 0 & 0 \\
\hline Kelapa Bakar & 8 & 7 & $87,5 \%$ \\
\hline Ubi jalar & 8 & 1 & $12,5 \%$ \\
\hline Total & 32 & 11 & $34,25 \%$ \\
\hline
\end{tabular}

Jenis kelamin dari tikus yang tertangkap dapat lebih jelasnya dilihat pada gambar dibawah ini :
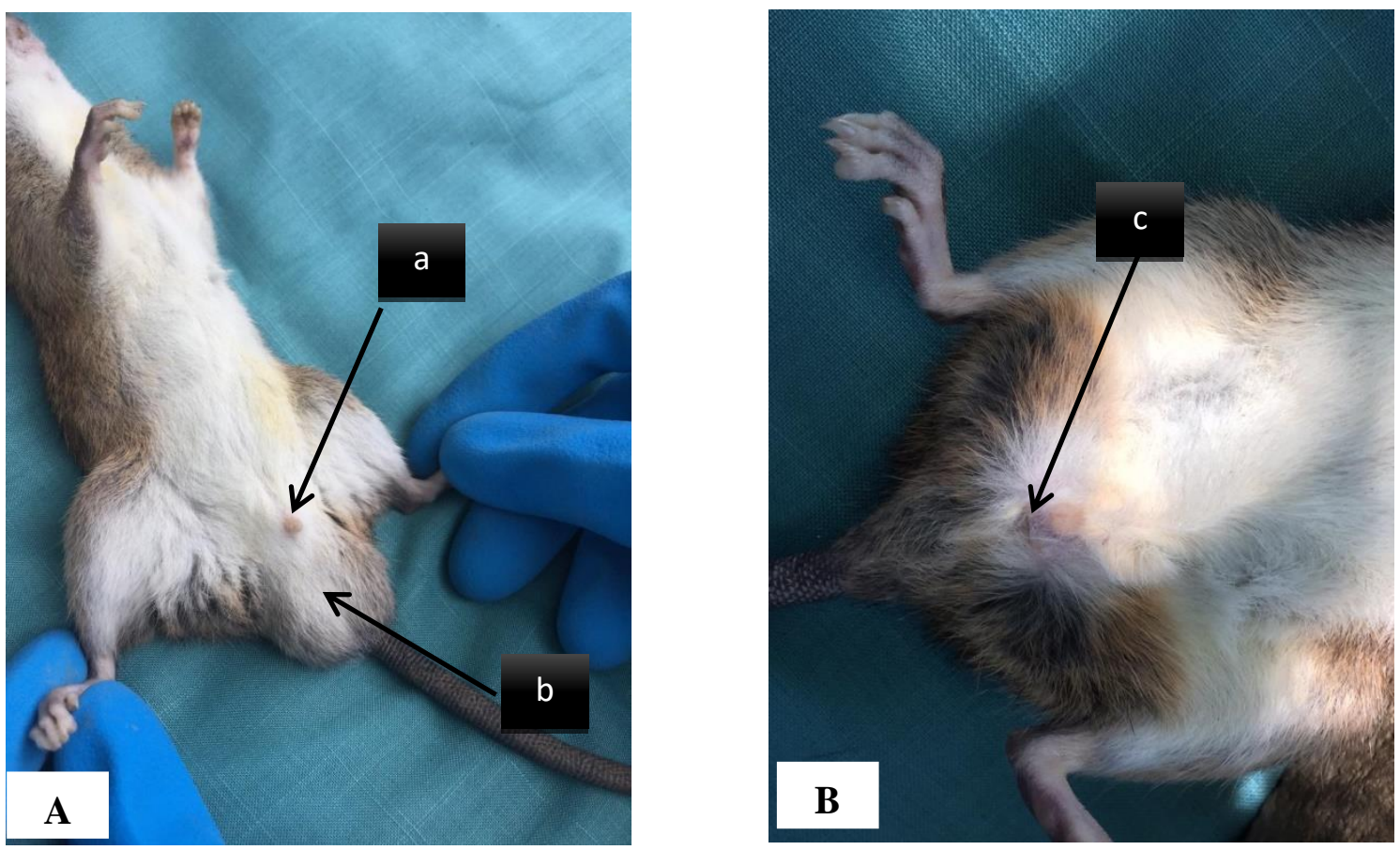

Gambar 1. (A) Anatomi organ reproduksi tikus jantan dan (B) Anatomi organ reproduksi tikus betina. (Keterangan : a. Penis ; b. Testis ; c. Vagina)

Berdasarkan gambar 1 dapat dilihat perbedaan jenis kelamin dari jantan dan betina pada tikus (Gambar 1). Tampak pada tikus jantan (Gambar A) memiliki penis dan testis, sedangkan tikus betina (Gambar B) tidak terlihat adanya testis atau penis.

Hasil penelitian tentang data keberhasilan pemerangkapan berdasarkan habitat pemerangkapan, $R$. Exulans lebih banyak didapatkan di rumpun bambu dibandingkan dengan kebun sedangkan $S$. murinus lebih banyak didapatkan di kebun dibandingkan dengan rumpun bambu. Habitat rumpun bambu yang paling banyak didapatkan tikus. Untuk data selengkapnya disajikan pada tabel 5 . 
Tabel 4. Keberhasilan pemerangkapan berdasarkan spesies, jenis kelamin, dan bobot tubuh.

\begin{tabular}{ll}
\hline Peubah yang diamati & Jumlah (ekor) \\
\hline Spesies & \\
Rattus exulans & 5 ekor \\
Hylomys suillus & 1 ekor \\
Suncus murinus & 5 ekor \\
\hline Jenis Kelamin & \\
Jantan & 3 ekor \\
Betina & 8 ekor \\
\hline Bobot Tubuh & \\
$>70 \mathrm{gr}$ & 3 ekor \\
$<70 \mathrm{gr}$ & 8 Ekor \\
\hline
\end{tabular}

Tabel 5. Keberhasilan pemerangkapan berdasarkan spesies tikus dan habitat.

\begin{tabular}{ccccc}
\hline $\begin{array}{c}\text { Habitat } \\
\text { Pemerangkapan }\end{array}$ & $\begin{array}{c}\text { Rattus } \\
\text { exulans }\end{array}$ & $\begin{array}{c}\text { Hylomys } \\
\text { suillus }\end{array}$ & $\begin{array}{c}\text { Suncus } \\
\text { murinus }\end{array}$ & Jumlah \\
\hline Rumpun Bambu & 5 & 1 & - & 6 \\
\hline Kebun & 2 & - & 3 & 5 \\
\hline Jumlah & 7 & 1 & 3 & 11 \\
\hline
\end{tabular}

\section{PEMBAHASAN}

Pada penelitian ini spesies tikus yang tertangkap adalah tikus ladang ( $R$. exulans). Sedangkan cecurut yang terperangkap adalah cecurut babi $(H$. suillus ) dan cecurut rumah ( $S$. murinus). Jika suatu wilayah masih dapat dijumpai tikus diduga karena sanitasinya yang masih kurang baik. Tikus ladang banyak dijumpai di semak-semak, kebun, sawah dan pinggiran hutan dan kadang-kadang masuk ke rumah.

Dalam penelitian ini ada juga hewan yang terperangkap kecuali tikus, didapatkan pula jenis cecurut dari spesies S. murinus dan $H$. suillus. Menurut Ristiyanto et al. (2006) cecurut adalah hewan insektivora yang cenderung beraktivitas di luar rumah daripada di dalam rumah, seperti membuat sarang, berkembang biak, berlindung, dan mencari makan. Secara morfologi cecurut apabila dilihat sepintas terkadang disamakan dengan tikus, namun bila diamati lebih detail terdapat beberapa perbedaan.
Moncong cecurut umumnya lebih panjang dan lebih runcing daripada tikus. Kaki depannya memiliki lima jari panjang yang bercakar tajam, berbeda dengan tikus yang memiliki jari yang pendek pada kaki bagian depan dan berkuku rata, tidak bercakar tajam. Semua gigi cecurut membundar atau membentuk kerucut berujung tajam, sedangkan gigi seri depan tikus membusur atau melengkung (memiliki tepi pemotong seperti sebuah ahat), dan terpisah dari gigi geraham yang relatif lebih besar oleh celah yang lebar (Payne et al., 2000).

Hewan dari golongan Insectivora ini memakan serangga sebagai makanan utama. Serangga yang sering dimakan oleh golongan insectivora antara lain kumbang, belalang, ulat, kupu-kupu, jangkrik, laba-laba, siput, cacing tanah, kelabang, dan kaki seribu. Selain memakan serangga, cecurut juga diketahui memakan burung, tikus, dan ular yang berukuran lebih kecil dari tubuhnya. Bahkan 
ketika dalam keadaan tertentu, cecurut memakan individu lain. Selain memakan serangga dan daging, Insectivora juga memakan makanan nabati seperti biji-bijian, akar, dan beberapa jenis tumbuhan untuk memperlancar pencernaan mereka (Schmidt, 1994). Keberadaan cecurut dapat dijadikan salah satu indikator bahwa daerah tersebut memiliki keadaan sanisitasi yang kurang baik dan masih kurang terjaga kebersihannya.

Berdasarkan Tabel 1 dapat diketahui jumlah spesies tikus ladang 5 ekor, cecurut rumah 5 ekor dan cecurut babi 1 ekor. Jenis kelamin tikus yang tertangkap lebih banyak betina dibandingkan dengan jantan hasil tersebut sejalan dengan penelitian yang dilakukan oleh Purwanto di Pelabuhan Tanjung Emas Semarang (2005). Banyaknya tikus betina tertangkap disebabkan oleh sifat tikus betina lebih aktif untuk mencari makan sedangkan jantan berperan menjaga sarang atau wilayah teritorialnya (Annashr et al., 2011).

Pada hari ke-4 pemerangkapan, tikus dan cecurut tidak sama sekali terperangkap namun umpan pada perangkap hilang diduga umpan dimakan oleh tikus namun tikus berhasil keluar dari perangkap. Hal ini diduga karena ukuran tikus yang terlalu besar sehingga saat tikus mengambil umpan, pintu perangkap tertahan oleh badan tikus sehingga dapat kembali keluar dari perangkap. Keberhasilan pemerangkapan dipengaruhi oleh beberapa faktor yaitu pemilihan umpan, posisi peletakan perangkap, dan durasi pemasangan perangkap (Armando, 2016). Selain itu, ukuran tikus dapat berpengaruh terhadap keberhasilan pemerangkapan.

Sedangkan pada hari ke-9 tikus dan cecurut juga tidak terperangkap, karena pada hari pemerangkapan tersebut cuaca sedang turun hujan. Rata-rata curah hujan pada saat pemerangkapan adalah sedang sampai tinggi. Tikus lebih mudah didapat pada saat curah hujan sedang dibandingkan saat curah hujan tinggi hal tersebut sesuai dengan penelitian yang dilakukan oleh Ade Nendi (2014). dapat bersifat kanibal dengan

Kondisi cuaca dapat mempengaruhi perilaku mamalia kecil dalam mencari makan, hal ini karena berkaitan dengan kondisi fisiologis tubuhnya yang akan membutuhkan energi lebih banyak pada saat suhu lingkungan cenderung dingin kondisi tersebut menyebabkan tikus cepat lapar dan membuthkan makanan lebih banyak, sehingga tikus masuk perangkap yang didalamnya terdapat sumber makanan.

Berdasarkan hasil pengamatan dari keempat jenis umpan, kelapa bakar merupakan umpan yang paling disukai oleh tikus dengan besar keberhasilan pemerangkapan $87,5 \%$. Kelapa bakar merupakan umpan yang sudah biasa digunakan dalam pemerangkapan tikus. Hal tersebut sesuai dengan pernyataan Junianto dan Siwiendrayanti (2016) yang menyatakan, kelapa bakar merupakan jenis umpan yang biasa digunakan dan merupakan standar dari WHO yang digunakan dalam pemerangkapan tikus karena kelapa bakar dapat bertahan lama dan tidak mudah rusak walaupun terkena hujan.

Tikus adalah hewan yang mempunyai indera penciuman yang sangat tajam. Aroma kelapa bakar yang sangat menyengat dapat menarik tikus untuk masuk ke dalam perangkap. Kelapa bakar merupakan jenis umpan yang paling disukai oleh tikus, karena memiliki aroma yang sangat kuat (Dedi 2012; Nasir et al. 2012). Masing-masing umpan memiliki kandungan yang diperlukan oleh tubuh tikus yaitu ubi jalar sebagai sumber karbohidrat, kelapa bakar sebagai sumber lemak, sedangkan tulang ayam dan ikan asin sebagai sumber protein.

Tikus merupakan hewan omnivora yang akan memilih makanan yang berkadar gizi seimbang, tikus umumnya membutuhkan $75-80 \%$ karbohidrat, $12-20 \%$ protein dan $4-6 \%$ lemak. Ikan asin digunakan sebagai umpan karena memiliki bau yang menyengat sehingga dapat menarik tikus masuk ke dalam perangkap, selain itu pemerangkapan tikus menggunakan umpan ikan asin sudah biasa dilakukan untuk memerangkap tikus di permukiman. Trap-shyness 
merupakan sifat tikus yang mampu beradaptasi dengan perangkap sehingga tikus sulit untukterperangkap. Namun selain sifat tersebut, faktor genetik juga dapat mempengaruhi keefektifan penggunaan perangkap yaitu pada saat dimana awal pemerangkapan tikus mudah didapat tetapi pada saat pemerangkapan selanjutnya tikus sulit didapat (Darmawansyah, 2008). Tingkah laku tikus juga bisa mempengaruhi keberhasilan pemerangkapan. Tikus merupakan hewan yang mempunyai indera penciuman dan pendengaran yang baik serta otak yang berkembang dengan baik sehingga tikus mampu belajar dari pengalaman (Priyambodo,2006).

Berdasarkan Tabel 4. tikus betina lebih banyak terperangkap dibandingkan dengan tikus jantan, hal tersebut sesuai dengan Nasir dan Mahmud (2012) yang menyatakan betina akan lebih banyak tertangkap pada musim melahirkan dan menyusui karena pada keaadan tersebut betina lebih banyak membutuhkan asupan makanan. Tikus betina menjadi individu pencari makan untuk anakanaknya sedangkan jantan sebagai penjaga sarang atau wilayah teritorialnya (Priyambodo, 2003). Menurut ivak (2014) tikus betina dan tikus-tikus berukuran besar lebih mudah ditangkap karena semakin berat bobot tubuh maka semakin berkurangnya kekuatan mobilitasnya.

Tikus dengan bobot kurang dari $70 \mathrm{~g}$ lebih banyak didapat dibandingkan dengan bobot yang lebih dari $70 \mathrm{~g}$. Hal tersebut berbanding terbalik dengan pernyataan Priyambodo (2003) yang menyatakan tikus dewasa $(>70 \mathrm{~g})$ lebih sering mencari makan, sehingga tikus berukuran kecil kemungkinan tertangkap lebih kecil.

Pada penelitian ini rumpun bambu merupakan habitat yang paling banyak didapatkanya tikus hal ini diduga karena karena rumpun bambu terdapat semak belukar sehingga sebagai tempat membuang sarang. Rumpun bambu merupakan daerah teritorial untuk spesies tikus ladang. Namun sebenarnya pola habitat tikus hidup berbeda beda, hal tersebut tidak membatasi wilayah penyebaran tikus (Meehan, 1984). Menurut Nasir et al. (2012), R. Exulans mempunyai daya adaptasi yang tinggi dan penyebaran yang luas terhadap makanan dan perbedaan lingkungan. Pada habitat kebun lebih dominan ditemukan spesies cecurut rumah. Cecurut rumah merupakan jenis hewan yang kosmopolitan yaitu dapat dijumpai di perkebunan, dan dalam rumah namun terkadang dapa ditemui juga di hutanhutan sekunder.

\section{KESIMPULAN}

Berdasarkan hasil dan pembahasan maka dapat disimpulkan bahwa keberhasilan pemerangkapan tikus dengan menggunakn jenis umpan yang berbeda adalah umpan yang paling disukai oleh tikus di Kebun Raya Liwa adalah kelapa bakar dengan keberhasilan pemerangkapan $87,5 \%$, ada 3 spesies yang tertangkap yaitu 1 jenis tikus yaitu Rattus exulans (Tikus Ladang), dan 2 jenis cecurut yaitu Suncus murinus (cecurut rumah) dan Hylomys suillus (cecurut babi). Dari keseluruhan 11 individu tikus dan cecurut yang tertangkap yang paling banyak adalah dibandingkan dengan jantan dan bobot tubuh kurang dari 70 gr lebih banyak tertangkap dibandingkan dengan bobot tubuh lebih dari $70 \mathrm{gr}$.

\section{DAFTAR PUSTAKA}

Annashr NN, Santoso L, Hestiningsih R. Studi kepadatan tikus dan ektoparasit di Desa Jomblang, Kecamatan Candisari, Kota Semarang tahun 2011. Wawasan Kesehatan. 2017;3(2):68-76.

Anonim, 2016. Kebun raya. http://lipi.go.id. Di akses pada 30 Agustus 2019 Pukul 14.50 WIB.

Aplin, K.P ., P .R. Brown, J. Jacob, C.J. Krebs, and G.R. Singleton. 2003. Field methods for rodent studies in Asia and Indo-Pacific. ACIAR Monograph. 100. 223p

Armando R. 2016. Pengaruh kondisi habitat kelapa sawit (Elaeis 
guineensis JACQ) terhadap artropoda dan hama tikus [tesis]. Bogor (ID): Institut Pertanian Bogor.

Astuti Desi, 2013,. Keefektifan Penggunaan Rodentisida Racun Kronis Generasi II Terhadap Keberhasilan Penangkapan Tikus Di Daerah Fokus Leptospirosis Kota Semarang [Skripsi], Universitas Negeri Semarang.

Darmawansyah A. Rancang bangun perangkap untuk pengendalian tikus rumah (Rattus rattus diardii Linn.) pada habitat permukiman [skripsi]. Bogor: Institut Pertanian Bogor; 2008.

Irawati J, Fibriana A I, Wahyono B. 2015. Efektivitas pemasangan berbagai model perangkap tikus terhadap keberhasilan penangkapan tikus di Kelurahan Bangetayu Kulon Kecamatan Genuk Kota Semarang Tahun 2014. UJPH 2(3): 67-75.

Ivakdalam LM. Uji Keefektifan enam jenis perangkap dalam pengendalian tikus sawah (Rattus argentiventer). J Agribisnis Kepul. 2014;2(2):3846.

Kern WH \& Kohler PG. 2007. Nonchemical Rodent Control. http://edis.ifas.ufl.edu.[23 November 2007]

Komariah, Pratita S, Malaka T. Pengendalian vektor. Jurnal Kesehatan Bina Husada. 2010; 6 (1): 34-43

Marbawati D, Ismanto H. 2011. Identifikasi tikus (pelatihan di laboratorium mamalia Lembaga Ilmu Pengetahuan Indonesia, Jakarta). Balaba 7 (2): 46-48.

Meehan AP. 1984. Rat and Mice, Their Biologi and Control. East Griendstead: Rentokil Limited.

Muriyanto, T. 2001. Pengaruh Tempat Peletakan Perangkap Bumbung dan Perangkap Kawat Terhadap Jumlah Tangkapan Tikus Sawah (Skripsi). Universitas Lampung. Bandar Lampung.

Natawigena, H. 2006. Entomologi Pertanian. Bandung: Orba Shakti.

Payne J, Francis CM, Phillips K, \& Kartikasari SN. 2000. Panduan
Lapangan Mamalia di Kalimantan, Sabah, Sarawak \& Brunei Darussalam : edisi Bahasa Indonesia. Wildlife Conservation Society : Jakarta

Priyambodo, S. 1995. Pengendalian Hama Tikus Terpadu. PT Panebar Swadaya. Jakarta. $53 \mathrm{hlm}$

Priyambodo S. 2003. Pengendalian Hama Tikus Terpadu. Jakarta (ID): Penebar Swadaya.

Priyambodo S. 2006. Tikus. Di dalam: Singgih HS dan Upik $\mathrm{KH}$, editor. Hama Permukiman Indonesia. Bogor: Unit Kajian Pengendalian Hama Permukiman (UKPHP). hlm 195-212.

Purwanto, S., Studi Kepadatan Tikus dan Pinjal di Pelabuhan Tanjung Emas Semarang Tahun 2005, Skripsi: Fakultas Kesehatan Masyarakat Universitas Diponegoro Semarang; 2005

Rodenticide Resistence Action Committee. 2015. Guidelines on anticoagulant rodenticide resistance management. Crop Life International. Brussels.

Rochman. 1992. Biologi dan Ekologi Tikus Sebagai Pengendalian Hama Tikus. Seminar Pengendalian Hama Tikus Terpadu. Institut Pertanian Bogor. Bogor. $17 \mathrm{hlm}$.

Schmidt RH. Shrews. 1994. Department of Fisheries and Wildlife, Utah University : Utah

Suyanto A. Rodent di Jawa. Bogor: LIPI; 2006.

Yuliadi, Muhidin, Indriyani S. 2016. Tikus Jawa, Teknik Survei di Bidang Kesehatan. Risyanto, Ahmadi AS, editor. Jakarta (ID): Lembaga Penerbit Badan Penelitian dan Pengembangan Kesehatan RI. 